\title{
Single-cycle rituximab-induced immunologic changes in children
}

Enhanced in neuroimmunologic disease?

\author{
Angela Deyà-Martínez, MD, PhD, Yadira Gordón, MD, Cristina Molina-Anguita, MD, \\ Alexandru Vlagea, MD, PhD, Monica Piquer, MD, PhD, Manel Juan, MD, PhD, Ana Esteve-Solé, PhD, \\ Jordi Antón, MD, PhD, Álvaro Madrid, MD, PhD, Ana García-García, MD, Ana M. Plaza, MD, PhD, \\ Thaís Armangue, MD, PhD, and Laia Alsina, MD, PhD
}

Neurol Neuroimmunol Neuroinflamm 2020;7:e724. doi:10.1212/NXI.0000000000000724

\author{
Correspondence \\ Dr. Alsina \\ lalsina@sjdhospitalbarcelona.org \\ or Dr. Armangué \\ armangue@clinic.cat
}

\begin{abstract}
Objective

To investigate the immunologic impact of a single cycle of rituximab (RTX) in children and adolescents with immune-mediated disorders, we evaluated B cells and immunoglobulin levels of 20 patients with neuroimmunologic, nephrologic, dermatologic, and rheumatologic disorders treated under recommended guidelines.
\end{abstract}

\section{Methods}

Retrospective study of immunologic changes in children (aged $\leq 18$ years) diagnosed with immune-mediated disorders in which RTX was prescribed between June 2014 and February 2019. Patients were excluded if they had prior diagnosis of malignant disease or primary immunodeficiency. Patients were clinically and immunologically followed up every 3 months. Only patients having received a single cycle of RTX and with a follow-up greater than 12 months were included in the analysis of persistent dysgammaglobulinemia.

\section{Results}

Twenty children were included. Median age at RTX treatment was 12.8 years (interquartile range [IQR] 6.6-15.5 years). Median follow-up was 12.6 months (IQR 10.2-24 months). Of the 14 patients eligible for persistent dysgammaglobulinemia analysis ( 3 had received RTX retreatment, 2 had $<12$ months post-RTX follow-up, and in 1 data for this time point was missing), 2/14 (14\%) remained with complete B-cell depletion, and 5/14 (36\%) had dysgammaglobulinemia. Patients with dysgammaglobulinemia were younger ( 7.8 vs 15.6 years, $p=0.072$ ), had more underlying neuroimmunologic diseases $(5 / 5 \mathrm{vs} 0 / 9, p<0.001)$, and had received more frequently concentrated doses of RTX ( $3 / 5$ vs $1 / 9, p=0.05)$ than patients without dysgammaglobulinemia. Kinetics of immunoglobulins in the 20 patients revealed a decrease as early as 3 months after RTX in patients with neuroimmunologic disorders.

\section{Conclusion}

In our cohort, single-cycle RTX-induced dysgammaglobulinemia was enhanced in patients with neuroimmunologic diseases. Further studies are needed to confirm this observation.

From the Clinical Immunology and Primary Immunodeficiencies Unit (A.D.-M., A.E.-S., A.G.-G., L.A.), Pediatric Allergy and Clinical Immunology Department (A.D.-M., Y.G., M.P., A.E.-S., A.G.-G., A.M.P., L.A.), Hospital Sant Joan de Déu, Barcelona, Spain; Institut de Recerca Sant Joan de Déu (A.D.-M., Y.G., M.P., A.E.-S., J.A., A.G.-G., A.M.P., L.A.), Barcelona, Spain; Clinical Immunology Unit Hospital Sant Joan de Déu-Hospital Clínic (A.D.-M., A.V., M.P., M.J., A.E.-S., A.G.-G., A.M.P., L.A.), Barcelona, Spain; Universitat de Barcelona (J.A., L.A., M.J.), Spain; Immunology Department (A.V., M.J.), Biomedical Diagnostics Center, Hospital Clinic-IDIBAPS, Barcelona, Spain; Pediatric Neuroimmunology Unit (C.M.-A., T.A.), Neurology Department, Hospital Sant Joan de Déu, University of Barcelona, Barcelona, Spain; Neuroimmunology Program (T.A.), Institut D'Investigacions Biomèdiques (IDIBAPS), Hospital Clinic, University of Barcelona, Barcelona, Spain; Pediatric Rheumatology Division (J.A.), Hospital Sant Joan de Déu, Barcelona, Spain; and Pediatric Nephrology Department (Á.M.), Hospital Sant Joan de Déu, Barcelona, Spain.

Go to Neurology.org/NN for full disclosures. Funding information is provided at the end of the article.

The Article Processing Charge was funded by the project PI15/01094 integrated in the Plan Nacional de I + D + I and cofinanced by the ISCIII-Subdirección General de Evaluación y Formento de la Investigación Sanitaria-and the Fondo Europeo de Desarrollo Regional (FEDER). 


\section{Glossary}

Ig = immunoglobulin; IRT = immunoglobulin replacement therapy; RTX = rituximab.

Rituximab (RTX), used as first-line or second-line treatment in many immune-mediated disorders, is a chimeric monoclonal antibody, which recognizes human CD20 expressed on B lymphocytes, leading to their destruction. ${ }^{1-3}$

It is well attested that B-cell depletion occurs within days after RTX, affecting from pro-B cells to plasmablasts. B-cell reconstitution to reach pretreatment levels, mostly studied in adult populations, ranges from 2 months to more than 2 years after RTX administration. The factors involved in this reconstitution remain unclear, but treatment duration, underlying disease, age, concomitant treatments, and previous immunologic status have been described as putative factors. ${ }^{3,4}$

Although long-lived plasma cells are not affected, a decrease in immunoglobulin levels is often observed after RTX treatment, predominantly affecting the immunoglobulin (Ig) M isotype. When this decrease is observed, most patients recover within 12 months following RTX administration. ${ }^{5-7}$ In some patients, severe hypogammaglobulinemia of $\mathrm{IgG}$ isotype occurs, requiring immunoglobulin replacement therapy (IRT). ${ }^{4}$

Despite the benefit of RTX in certain immune-mediated disorders, there are concerns regarding the risk of associated secondary immunodeficiency, which is frequently amplified in this population by the use of other concomitant immunosuppressant therapies. ${ }^{8}$ This is of special interest in children, who are more exposed to infections and have an immune system in development. ${ }^{9}$

To increase our understanding of the immunologic changes and infectious risk related to RTX use in nononcologic diseases, we analyzed the effects of a single cycle of RTX for the treatment of immune-mediated disorders in a pediatric population.

\section{Methods}

Retrospective study of immunologic reconstitution between June 2014 and February 2019 under clinical practice conditions, including patients aged $\leq 18$ years, diagnosed with an immune-mediated disorder (nonmalignant diseases) comprising neuroimmunologic, nephrologic, dermatologic, and rheumatologic diseases, and treated with 1 induction cycle of RTX in accordance with the recommended guidelines or in-house protocols for each disease. ${ }^{10-12}$ All patients were followed at the Clinical Immunology Unit, in which a specific post-RTX immune reconstitution monitoring protocol has been developed that includes a clinical and analytical control every 3 months until full stable B-cell and immunoglobulin recovery is achieved (table 1). Patients having received a single cycle of RTX and with a follow-up greater than 12 months after RTX were included in the analysis of persistent dysgammaglobulinemia. The decision to choose the 12-month time point was based on previous publications showing that when dysgammaglobulinemia is observed after RTX, most patients recover within 12 months. ${ }^{5-7}$ Because only single-cycle RTX immunologic impact was analyzed, once a patient received a second cycle of RTX, they were excluded for subsequent analysis. Patients with a previous diagnosis of malignant disease or primary immunodeficiency were excluded. The study has been reviewed and approved for its publication by the ethics committee of our institution.

We obtained patient information (sex, age at RTX infusion, ethnicity, consanguinity and family history, RTX dosage, concomitant immunosuppression, and infections) from clinical charts or interviews during follow-up visits. For the analysis, RTX dosage was categorized as concentrated regimen (1-2 doses at $500-750 \mathrm{mg} / \mathrm{m}^{2}$ separated by 2 weeks) vs nonconcentrated regimen (4 weekly doses at $375 \mathrm{mg} / \mathrm{m}^{2}$ ). Laboratory data analysis included complete blood count; immunoglobulin levels (IgG, IgM, and IgA [ARCHITECT c Systems and AEROSET System. Immunoturbidimetric measure]); percentage of $\mathrm{CD}^{+} \mathrm{T}$ cells, $\mathrm{CD}^{+} \mathrm{T}$ cells, $\mathrm{CD} 19^{+} \mathrm{B}$ cells, and B-cell immunophenotyping (naive $\left[\mathrm{CD} 19^{+} \mathrm{IgM}+/ \mathrm{IgD}+\right]$; memory $\left[\mathrm{CD} 19^{+} \mathrm{CD} 27^{+} \mathrm{IgD}+\right]$, switched memory $\left[\mathrm{CD} 19^{+} \mathrm{CD} 27^{+} \mathrm{IgD}-\right]$, and plasmablasts $\left[\mathrm{CD} 19^{+} \mathrm{IgM}-\mathrm{CD} 38^{++}\right]$) (flow cytometry using BD Biosciences, San Jose, CA, USA, FACS Canto II, normal range for age obtained from Schatorjé et al. ${ }^{13}$ ). Dysgammaglobulinemia was defined as a decrease of $2 \mathrm{SDs}$ below age reference values of at least $1 \mathrm{immunoglobulin}$ isotype (IgG and/or IgM and/or IgA). ${ }^{14}$

\section{Statistical analysis}

Categorical and continuous variables were described as percentages and median values and IQR (p25-p75). We applied the Fisher exact test or Mann-Whitney $U$ test for the comparative analysis of baseline characteristics and at 12 months post-RTX as appropriate for the data set. We used Pearson and Spearman tests to identify correlations between quantitative variables. The analysis was performed using SPSS version 15.0 software (SPSS Inc., Chicago, IL), and statistical significance was set at $p \leq 0.05$.

\section{Results}

We recruited a total of 20 patients comprising neuroimmunologic, nephrologic, dermatologic, and rheumatologic diseases (table e-1, links.lww.com/NXI/A242). Median age at first RTX was 12.8 (IQR 6.6-15.5) years. Of note, $8 / 20$ patients received the concentrated RTX regimen and $12 / 20$ the 4-weekly regimen according to the recommendations for each disease. ${ }^{10-12}$ All patients had received immunosuppressants previously and/or concomitant with RTX (9/20 [45\%] steroids alone; 11/20 [55\%] steroids and second-line immunosuppressants) (table e-1, links.lww.com/NXI/A242). 
Table 1 Protocol for immunologic follow-up of patients treated with RTX in our center

\begin{tabular}{|c|c|c|c|c|c|c|c|}
\hline & Baseline & $3 \mathrm{mo}$ & $6 \mathrm{mo}$ & $9 \mathrm{mo}$ & $12 \mathrm{mo}$ & $18 \mathrm{mo}^{\mathrm{a}}$ & $24 \mathrm{mo}^{a}$ \\
\hline CD19 $^{+}$B cells & $x$ & $x$ & $x$ & $x$ & $x$ & $x$ & $x$ \\
\hline B-cell subphenotype & $x$ & & & & $x$ & $x$ & $x$ \\
\hline IgG, M, and A levels & $x$ & $x$ & $x$ & $x$ & $x$ & $x$ & $x$ \\
\hline \multicolumn{8}{|c|}{$\begin{array}{l}\text { Recommendations for immunoglobulin replacement therapy: } \\
\text { - Patients aged }<2 \text { years at the first dose of RTX in any patient irrespectively of IgG count during B-cell aplasia } \\
\text { - Patients aged }>2 \text { years } \\
\text { Hypo-lgG }<200 \mathrm{mg} / \mathrm{dL} \text { (IgG }<300 \mathrm{mg} / \mathrm{dL} \text { is a relative indication) } \\
\text { Well-documented impaired responses to vaccines before RTX-sinopulmonary infections or infections caused by capsular bacteria attributed to } \\
\text { hypogammaglobulinemia } \\
\text { Other immunosuppressant treatments administered concomitantly with RTX, especially high-dose steroids and cyclophosphamide. Other treatments } \\
\text { should be individualized. }\end{array}$} \\
\hline
\end{tabular}

Abbreviations: Ig = immunoglobulin; RTX = rituximab.

$18 \mathrm{mo}$ and 24 mo controls were only performed if no complete immune reconstitution was achieved before these timepoints.

${ }^{b}$ B-cell subphenotype includes naive (CD19 IgM+/IgD+), switched memory (CD19 ${ }^{+}$CD2 $7^{+}$IgD-), and plasmablasts (CD19 ${ }^{+}$IgM-CD38 ${ }^{++}$). B-cell subphenotype also analyzed every 3 mo if retreatment with RTX is considered.

All but 1 patient with underlying nephrotic syndrome (P17, figure e-1, links.lww.com/NXI/A240) had normal IgG levels before RTX. Two patients had low baseline levels of B-cell percent, and 2 patients showed low baseline switched memory B cells (table e-1, links.lww.com/NXI/A242, and table e-2, links.lww.com/NXI/A243).

The presence of dysgammaglobulinemia was analyzed 12 months after RTX: After excluding 6 patients ( 3 because of additional RTX cycles before 12 months, 2 because they had not reached 12 months of follow-up, and in one data was missing for this timepoint), 14 patients remained on follow-up at 12 months after receiving RTX (figure e-1, links.lww.com/NXI/ A240). Regarding B cells, $2 / 14$ patients (14.3\%, P6 and P12) remained with complete B-cell depletion, and $9 / 14$ (64.3\%) had not reached normal percentage of $B$ cells (table e-2, links.lww. com/NXI/A243). B-cell subphenotype showed normal or high per age range values of naive B-cell levels in all patients, while 3 / 9 patients had low levels of B memory cells and $6 / 9$ had normal levels (table e-2, links.lww.com/NXI/A243). Of the 6 patients on follow-up 24 months post-RTX, because they had not previously reached fully immune recovery and were not RTXretreated, 3/6 remained with low levels of B cells.

Regarding immunoglobulin levels, 5/14 (36\%) had some degree of persistent dysgammaglobulinemia (isolated hypo-IgG (1), isolated hypo-IgA (1), hypo-IgG and A (1), hypo-IgG and $\operatorname{IgM}(1)$, and hypo-IgA and $M(1)$ ), affecting IgG concentrations in 3 . At 24 months post-RTX, 2/6 persisted with dysgammaglobulinemia.

\section{Comparative analysis between patients with and without dysgammaglobulinemia 12 months after RTX}

We observed differences in demographics and underlying disease in patients with or without dysgammaglobulinemia (table 2): the 5 patients with dysgammaglobulinemia showed a tendency toward being younger at the time of RTX treatment ( 7.8 years vs $15.6 ; p=0.072$ ), all had underlying neuroimmunologic diseases $(5 / 5$ vs $0 / 9$ patients; $p<0.001)$, and they had received more frequently the concentrated RTX regimen $(3 / 5$ vs $1 / 9 ; p=0.05)$ in comparison with patients without dysgammaglobulinemia. No increased use of previous or concomitant immunosuppressants was observed in the group with dysgammaglobulinemia. Indeed, most patients with underlying neuroimmunologic conditions, which more frequently developed dysgammaglobulinemia, received steroids alone (only 1 patient combined with cyclophosphamide) before RTX (table e-1, links.lww. com/NXI/A242, and table 2).

No statistically significant differences were found between the 2 groups regarding baseline IgG, IgM, and IgA levels $(\operatorname{IgG} p=0.178, \operatorname{IgM} p=0.966, \operatorname{IgA} p 0.299)$. The percentage of basal B cells was lower in patients with neuroimmunologic disease (10\%) in contrast to nonneuroimmunologic disease (31\%) $(p=0.01$, figure e-2, links.lww.com/NXI/A241), but the levels were not pathologic in any of the groups, and no differences in B-cell subphenotype were observed (table 2).

To gain insight in the characteristics of the dysgammaglobulinemia, we evaluated the kinetics on its evolution. Figure 1 represents the kinetics of instauration of dysgammaglobulinemia in the 20 patients included in the cohort. Three months after RTX treatment, patients with underlying neuroimmunologic disorders already showed a tendency toward lower levels of immunoglobulins $(\operatorname{IgG} p=0.267, \operatorname{IgM} p=0.087, \operatorname{IgA} p 0.075)$, which at 6 $(\operatorname{IgG} p=0.036, \operatorname{IgM} p=0.011, \operatorname{IgA} p 0.015)$ and 12 months (IgG $p=0.048, \operatorname{IgM} p=0.046, \operatorname{IgA} p 0.029)$ was statistically significant. At 24 months, 4 patients persisted with some degree of decreased B-cell numbers and/or dysgammaglobulinemia, of which 3 had an underlying neuroimmunologic disease.

Despite 5 patients developed dysgammaglobulinemia, only 1 patient (P6 who previously received cyclophosphamide) 
Table 2 Comparison between patients with and without dysgammaglobulinemia 12 months after a single cycle of RTX

\begin{tabular}{|c|c|c|c|}
\hline & $\begin{array}{l}\text { Patients with } \\
\text { dysgammaglobulinemia, } N=5\end{array}$ & $\begin{array}{l}\text { Patients with normal } \\
\text { immunoglobulin levels, } N=9\end{array}$ & $p$ Value \\
\hline Age $(y)$ at disease onset (median, IQR) & $3(2.5-11)$ & $4(3-14.5)$ & 0.366 \\
\hline Disease duration before the first RTX (y) (median, IQR) & $0.4(0.2-3.7)$ & $3.7(0.9-9.7)$ & 0.125 \\
\hline Age $(y)$ at the first RTX infusion (median, IQR) & $7.8(2.9-12.3)$ & $15.6(7.1-16.1)$ & $0.072^{a}$ \\
\hline Female & $3 / 5$ & $6 / 9$ & 1.000 \\
\hline Caucasian & $3 / 5$ & $8 / 9$ & 0.505 \\
\hline Family history of autoimmune diseases & $1 / 5$ & $1 / 9$ & 1.000 \\
\hline Underlying neuroimmunologic disease & $5 / 5^{b}$ & $0 / 9$ & $<0.00^{a}$ \\
\hline Nephrologic diseases & $0 / 5$ & $6 / 9$ & 0.031 \\
\hline Pre-RTX low \% of B cells & $0 / 5$ & $2 / 8^{a}$ & 0.487 \\
\hline Pre-RTX low \% naive B cells & $1 / 4$ & $2 / 6$ & 1.000 \\
\hline Pre-RTX plasmablasts below $1 \%$ & $3 / 4$ & $1 / 6$ & 0.190 \\
\hline Pre-RTX low switched memory B cells & $1 / 5$ & $1 / 9$ & 0.881 \\
\hline Pre-RTX low IgG levels & $0 / 5$ & $0 / 9$ & - \\
\hline Pre-RTX use of cyclophosphamide & $1 / 5$ & $2 / 9$ & 0.661 \\
\hline Pre-RTX use of purine analogs & $1 / 5$ & $4 / 9$ & 0.043 \\
\hline Immunosuppressive treatment before RTX & $\begin{array}{l}\text { Steroids alone: } 4 / 5 \\
\text { Steroids + second-line IS:1/5 }\end{array}$ & $\begin{array}{l}\text { Steroids alone: 0/9 } \\
\text { Steroids + second-line IS:9/9 }\end{array}$ & $\begin{array}{l}0.001^{\mathrm{a}} \\
0.001^{\mathrm{a}}\end{array}$ \\
\hline Concomitant use of cyclophosphamide & $0 / 5$ & $0 / 9$ & - \\
\hline Concomitant use of purine analogs & $1 / 5$ & $5 / 9$ & 0.095 \\
\hline Concomitant use of other immunosuppressive (IS) B treatment & $\begin{array}{l}\text { Steroids alone:1/5 } \\
\text { Steroids + second-line IS:1/5 }\end{array}$ & $\begin{array}{l}\text { Steroids alone: } 1 / 9 \\
\text { Steroids + second-line IS: } 8 / 9\end{array}$ & $\begin{array}{l}0.649 \\
0.010\end{array}$ \\
\hline Use of concentrated $\mathrm{RTX}$ regimen ${ }^{c}$ & $3 / 5$ & $1 / 9$ & $0.05^{a}$ \\
\hline \multicolumn{4}{|l|}{12 mo post-RTX } \\
\hline B cells $=0 \%$ & $1 / 5$ & $1 / 9$ & 1.000 \\
\hline B cells $\%>0$ and $<2 \%$ & $1 / 5$ & $2 / 9$ & 1.000 \\
\hline Total patients with low percentage of B cells according to age range & $2 / 5$ & $7 / 9$ & 0.266 \\
\hline Low absolute B cell levels according to age range & $4 / 5$ & $5 / 9$ & 0.580 \\
\hline High levels of naive B cells (\%) & $3 / 4$ & $2 / 7$ & 0.242 \\
\hline Low levels of memory B cells (\%) & $2 / 4$ & $1 / 5$ & 0.524 \\
\hline Plasmablasts below $1 \%$ & $1 / 4$ & $2 / 7$ & 1.000 \\
\hline
\end{tabular}

Abbreviations: Ig = immunoglobulin; IQR = interquartile range; RTX = rituximab.

${ }^{\text {a }}$ Risk factors for developing persistent dysgammaglobulinemia 12 mo after RTX.

b 3 recurrent anti-myelin oligodendrocyte glycoprotein-associated inflammatory central nervous disease; 2 anti-NMDA receptor encephalitis.

c Concentrated RTX regimen: 1 to 2 doses at $500-750 \mathrm{mg} / \mathrm{m}^{2}$ separated by 2 weeks.

required IRT because of a severe hypogammaglobulinemia due to a prolonged B-cell aplasia after a first cycle of RTX. An additional patient (P3) required IRT after retreatment with RTX because of severe hypogammaglobulinemia and bacterial pneumonia. No other relevant infections were reported in the remaining patients.

\section{Discussion}

This study describes the demographic characteristics, immunologic changes, and clinical outcomes of 20 children with acquired immune-mediated disorders after a single cycle of RTX. The results of our analysis provide insights regarding the apparent 
Figure 1 Post-RTX evolution of immunoglobulin levels ((A) IgG, (B) $\lg M$, and (C) $\lg A$ ) in pediatric patients with neuroimmunologic vs non-neuroimmunologic diseases (IgG levels are expressed using normalized levels according to normal age ranges)

$\square$ Neuroimmunologic

$\square$ Non-neuroimmunologic

$\star \star p<0.001$
A. IgG evolution

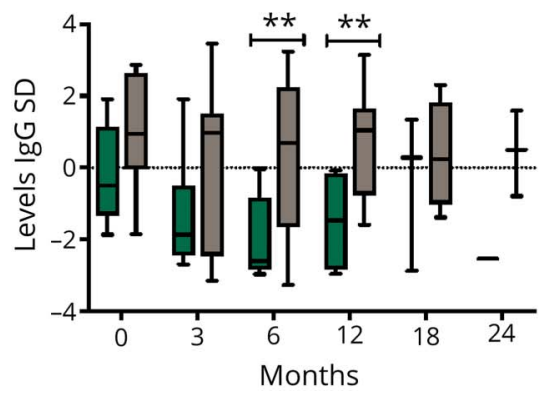

B. IgM evolution

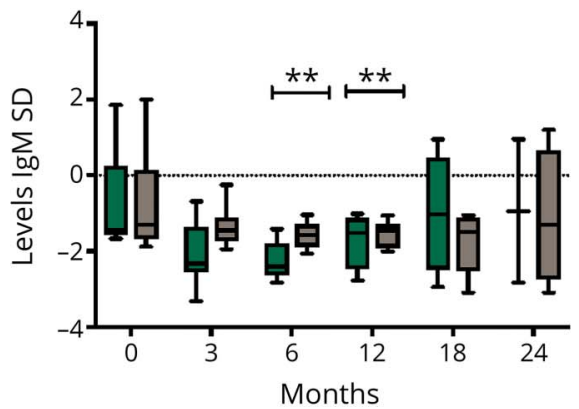

C. IgA evolution

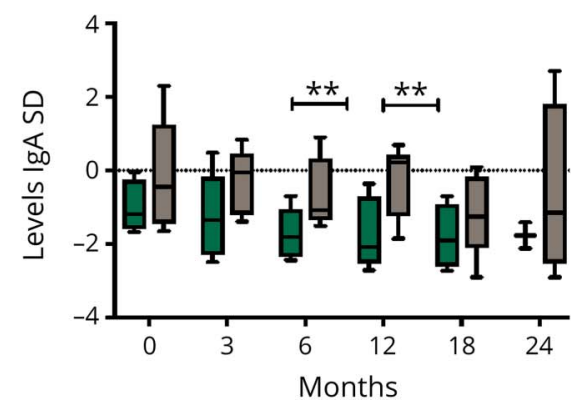

One patient with baseline hypo IgG due nephrotic syndrome (P17) was not included for the IgG kinetics analysis. Ig = immunoglobulin; RTX = rituximab.

good tolerance to RTX in pediatric patients with immunemediated disorders, except for a possible enhanced susceptibility to dysgammaglobulinemia in neuroimmunologic diseases.

In adults receiving RTX for nononcologic diseases, complete B-cell count recovery usually occurs at 2-6 months. ${ }^{5,6}$ In the context of malignancy, the recovery takes place 1-2 years afterward or later. $^{5-7}$ There is a lack of systematic immunologic follow-up of pediatric patients receiving RTX, but recent studies reveal that in nononcologic conditions, recovery of B cells occurs later than in adults at 6-12 months. ${ }^{15,16}$ This timing is consistent with our observations. Complete B-cell depletion at 12 months post-RTX can be seen in up to $10 \%$ of patients. ${ }^{17}$ In our cohort, at 12 months post-RTX, $64.3 \%$ of patients had not yet reached full B-cell reconstitution, higher than expected, and 2/14 remained with complete B-cell depletion (table e-2, links.lww.com/NXI/A243).

There are a few published reports regarding B-cell subphenotype in RTX-treated patients. It has been reported that patients with previously decreased switched memory B cells may be at a greater risk of developing abnormalities and hypogammaglobulinemia. ${ }^{4}$ In our cohort, 2 patients showed low baseline levels of switched memory B cells, but only one of them developed dysgammaglobulinemia. On B-cell reconstitution, naive phenotype predominated, as expected, but interestingly, 12 months post-RTX, 6 patients already showed normal levels of memory B cells. No differences in the B-cell subphenotype on B-cell reconstitution were observed between patients who developed dysgammaglobulinemia and those who did not.

In terms of impaired antibody production, some factors have been associated such as certain underlying diseases, previous hypogammaglobulinemia, ${ }^{18}$ and concomitant chemotherapy, whereas others remain unknown. ${ }^{1,4,19}$ In our cohort, all patients (except 1 with nephrotic syndrome) had previous normal levels of immunoglobulins. In the majority of published studies conducted in adults with nononcologic diseases receiving RTX, the proportion of low IgM seems to be greater than the prevalence of low IgG. ${ }^{1}$ The data available on immunoglobulin levels after RTX in children with nonmalignant disease are nonhomogeneous. ${ }^{1}$ Although some report patients with immunoglobulins in the low level of normal range, others report mild hypogammaglobulinemia ${ }^{1}$; still, it seems that a major impact on IgM levels is observed as well. ${ }^{1,20-22}$

Persistent dysgammaglobulinemia 12 months after RTX is less commonly observed. ${ }^{1}$ In our cohort, 12 months after RTX, 5/14 (36\%) patients presented dysgammaglobulinemia (3/5 including hypo-IgG), despite complete recovery of B-cell count in 3 of them. Surprisingly, all patients with persistent dysgammaglobulinemia at 12 months had underlying neuroimmunologic diseases, and in 4/5, immunoglobulin level alterations had already appeared 3 months after RTX. This fast-established alteration is rarely reported ${ }^{23}$ and is even more significant if we consider that in 2/4 patients, these alterations persisted after 24 months. An important immunologic impact of RTX in neuroimmunologic patients (children and adults) has recently been reported, ${ }^{24,25}$ although many re-treated patients were included in the analysis, making the results not comparable to ours.

The observed selective occurrence of cases of persistent dysgammaglobulinemia among neuroimmunologic patients was unexpected. Factors that have been associated with higher risk of dysgammaglobulinemia and which might explain the enhanced humoral impact in these diseases in comparison with other immune-mediated diseases included are age at the time of RTX, more concentrated doses of RTX, concomitant 
immunosuppressants, and/or a possible previously undetected underlying immune disorder.

Regarding age at RTX treatment, patients with neuroimmunologic disorders were younger than the other group. This susceptibility associated with age has recently been reported in a similar pediatric cohort in patients with neuroimmunologic diseases. ${ }^{17}$ In fact, our post-RTX protocol based on published recommendations (table 1 ) indicates IRT in patients receiving RTX less than 2 years old due to the associated infectious risk ascribed to their reduced immune repertoire. ${ }^{26}$ Nevertheless, RTX was also administered in very young patients in the group of non-neurologic disorders, without consequences. Thus, age might only partially explain this observation.

Regarding RTX dose, 3/5 patients with neuroimmunologic disorders more frequently received the concentrated RTX regimen compared with the rest of the cohort. Although the cumulative dose is lower with this regimen $\left(1000\right.$ vs $\left.1500 \mathrm{mg} / \mathrm{m}^{2}\right)$, the intensity is higher. The recommendations for the use of higher doses of RTX in neuroimmunologic disorders are based on recent publications showing better clinical results compared with the less intense regimen. ${ }^{12}$ These good results are attributed to higher extravascular B-cell depletion ${ }^{27}$ and to increased CNS concentrations. ${ }^{12}$ Higher doses of RTX can induce another mechanism of B-cell depletion, causing a more prominent plasma cell destruction, which could explain this early immunoglobulin impairment. This phenomenon is called shaving. During shaving, RTX-CD20 complexes removed from B-cell surface are released through circulation, arriving at the bone marrow, where they link with FcyRIIIB-expressing plasma cells, leading to their apoptosis. ${ }^{28}$ Although this phenomenon may contribute to the observed early-onset dysgammaglobulinemia, it still does not explain the full picture because only $3 / 5$ patients with neuroimmunologic diseases received the concentrated RTX regimen.

Regarding the role of concomitant immunosuppressant treatment, in our cohort, all patients had previously received several lines of immunosuppressants. Indeed, 1 of the 2 patients with permanent complete B depletion ( $0 \%-1 \%$ B cell) had previously received cyclophosphamide, but 2 other patients of the cohort with non-neuroimmunologic diseases also received cyclophosphamide with no dysgammaglobulinemia. Curiously, patients with neuroimmunologic disorders had received fewer previous or concomitant immunosuppressants (table 2). In the literature, the results of the different published studies often display contradictory conclusions. ${ }^{29,30}$ Some correlate the use of cyclophosphamide and purine analogs ${ }^{31}$ or high doses of steroids with the development of hypogammaglobulinemia; however, mixed treatments used in clinical practice hamper the analysis of the specific impact of each drug on the immune system.

Finally, another hypothesis is the underlying disease itself because all patients with neuroimmunologic diseases developed dysgammaglobulinemia, irrespective of the regimen dose or age. It is difficult to elucidate the role of disease because the few published information on the immunologic impact of RTX in neuroimmunologic disorders has been obtained from adult cohorts in which RTX retreatment (monthly or every 6 months depending on the regimen and patient) represents the current management. ${ }^{23}$ Under these conditions, $30 \%$ of patients have been described to develop hypogammaglobulinemia at some stage during RTX therapy. ${ }^{23}$

In our cohort, we did not observe B-cell subphenotype differences at baseline or after RTX, and different neuroimmunologic diseases were included, with different mechanisms of pathogenesis (3/5 patients with recurrent anti-myelin oligodendrocyte glycoprotein-associated central nervous inflammatory disease and 2/5 with anti-NMDA receptor encephalitis), making it difficult to reinforce this hypothesis. Nevertheless, it cannot be ruled out that an unidentified intrinsic B-cell defect underlies these diseases, which might then be magnified by the use of high doses of RTX.

The sample size is a limitation of the study, and observations need to be replicated in larger studies. Nevertheless, the kinetics of the dysgammaglobulinemia in the subgroup of patients with neuroimmunologic disorders are consistent among the patients. Also, patients included in this study reflect common clinical practice.

In conclusion, we have analyzed single-cycle RTX-induced humoral alterations in a cohort of pediatric patients with immunerelated disorders. We have observed more frequent alterations than expected compared with previously published results, in particular in patients with neuroimmunologic diseases. Still, the increase in infectious risk is low. Patients with neuroimmunologic diseases show a particular pattern of dysgammaglobulinemia with early onset. This finding might be ascribed to a combination of the underlying disease, younger age, and/or higher concentration of RTX dose. These observations are of special interest because retreatment with RTX is becoming current practice in many of these diseases, which may increase the number of patients that develop dysgammaglobulinemia. ${ }^{10-12}$ Further studies are needed to confirm these observations and to explore the underlying immunologic mechanisms involved.

\section{Acknowledgement}

The authors would like to thank the "Biobanc de l'Hospital Infantil Sant Joan de Déu per a la Investigació” integrated in the Spanish Biobank Network of ISCIII for the sample and data procurement.

\section{Study funding}

This study was supported by the projects PI15/01094, PFIS0200 (AC16/00025), PI18/00223, and FI19/00208 to LA, and PI18/00486 to TA, integrated in the Plan Nacional de I + D + I and cofinanced by the ISCIII-Subdirección General de Evaluación y Formento de la Investigación Sanitaria-and the Fondo Europeo de Desarrollo Regional (FEDER), through the Pla estratègic de recerca i innovació en salut (PERIS), Departament de Salut, Generalitat de Catalunya (SLT006/17/ 00199 to LA and SLT006/17/00362 to TA), Mutua Madrileña Foundation (AP162572016 to TA), 2017 Leonardo Grant for Researchers and Cultural Creators, BBVA Foundation and 
a 2017 Beca de Investigación de la Sociedad Española De Inmunología Clínica Alergología y Asma Pediatrica to LA, and Torrons Vicens Foundation grant (PFNR0144) to LA and TA.

\section{Disclosure}

The authors report no disclosures relevant to the manuscript.Go to Neurology.org/NN for full disclosures.

\section{Publication history}

Received by Neurology: Neuroimmunology \& Neuroinflammation December 20, 2019. Accepted in final form March 17, 2020.

Appendix Authors

\begin{tabular}{lll}
\hline Name & Location & Contribution \\
\hline $\begin{array}{l}\text { Angela } \\
\text { Deyà- }\end{array}$ & Sant Joan de Déu Children's & $\begin{array}{l}\text { Designed and } \\
\text { conceptualized the } \\
\text { Martínez, }\end{array}$ \\
MD, PhD & study; performed the \\
& & $\begin{array}{l}\text { immunologic studies } \\
\text { and followed the }\end{array}$ \\
& patients; analyzed the \\
& data; drafted the \\
& manuscript; and \\
& developed the figures
\end{tabular}

\begin{tabular}{|c|c|c|}
\hline $\begin{array}{l}\text { Yadira } \\
\text { Gordón, MD }\end{array}$ & $\begin{array}{l}\text { Sant Joan de Déu Children's } \\
\text { Hospital, Barcelona, Spain }\end{array}$ & $\begin{array}{l}\text { Followed the patients } \\
\text { and drafted the } \\
\text { manuscript }\end{array}$ \\
\hline $\begin{array}{l}\text { Cristina } \\
\text { Molina- } \\
\text { Anguita, MD }\end{array}$ & $\begin{array}{l}\text { Sant Joan de Déu Children's } \\
\text { Hospital, Barcelona, Spain }\end{array}$ & $\begin{array}{l}\text { Followed the patients, } \\
\text { analyzed data, and } \\
\text { reviewed the } \\
\text { manuscript }\end{array}$ \\
\hline $\begin{array}{l}\text { Alexandru } \\
\text { Vlagea, MD, } \\
\text { PhD }\end{array}$ & $\begin{array}{l}\text { Hospital Clinic, Barcelona, } \\
\text { Spain }\end{array}$ & $\begin{array}{l}\text { Performed the } \\
\text { immunologic studies } \\
\text { and reviewed the } \\
\text { manuscript }\end{array}$ \\
\hline $\begin{array}{l}\text { Monica } \\
\text { Piquer, MD, } \\
\text { PhD }\end{array}$ & $\begin{array}{l}\text { Sant Joan de Déu Children's } \\
\text { Hospital, Barcelona, Spain }\end{array}$ & $\begin{array}{l}\text { Followed the patients, } \\
\text { analyzed data, and } \\
\text { reviewed the } \\
\text { manuscript }\end{array}$ \\
\hline $\begin{array}{l}\text { Manel Juan, } \\
\text { MD, PhD }\end{array}$ & $\begin{array}{l}\text { Sant Joan de Déu Children's } \\
\text { Hospital and Hospital Clínic, } \\
\text { Barcelona, Spain }\end{array}$ & $\begin{array}{l}\text { Performed the } \\
\text { immunologic studies } \\
\text { and reviewed the } \\
\text { manuscript }\end{array}$ \\
\hline $\begin{array}{l}\text { Ana Esteve, } \\
\text { PhD }\end{array}$ & $\begin{array}{l}\text { Sant Joan de Déu Children's } \\
\text { Hospital, Barcelona, Spain }\end{array}$ & $\begin{array}{l}\text { Performed the } \\
\text { immunologic studies } \\
\text { and reviewed the } \\
\text { manuscript }\end{array}$ \\
\hline $\begin{array}{l}\text { Jordi Anton, } \\
\text { MD, PhD }\end{array}$ & $\begin{array}{l}\text { Sant Joan de Déu Children's } \\
\text { Hospital, Barcelona, Spain }\end{array}$ & $\begin{array}{l}\text { Followed the patients } \\
\text { and reviewed the } \\
\text { manuscript }\end{array}$ \\
\hline $\begin{array}{l}\text { Alvaro } \\
\text { Madrid, MD, } \\
\text { PhD }\end{array}$ & $\begin{array}{l}\text { Sant Joan de Déu Children's } \\
\text { Hospital, Barcelona, Spain }\end{array}$ & $\begin{array}{l}\text { Followed the patients } \\
\text { and reviewed the } \\
\text { manuscript }\end{array}$ \\
\hline $\begin{array}{l}\text { Ana García- } \\
\text { García, MD }\end{array}$ & $\begin{array}{l}\text { Sant Joan de Déu Children's } \\
\text { Hospital, Barcelona, Spain }\end{array}$ & $\begin{array}{l}\text { Followed the patients, } \\
\text { analyzed data, and } \\
\text { reviewed the } \\
\text { manuscript }\end{array}$ \\
\hline $\begin{array}{l}\text { Ana María } \\
\text { Plaza, MD, } \\
\text { PhD }\end{array}$ & $\begin{array}{l}\text { Sant Joan de Déu Children's } \\
\text { Hospital, Barcelona, Spain }\end{array}$ & $\begin{array}{l}\text { Reviewed the } \\
\text { manuscript }\end{array}$ \\
\hline
\end{tabular}

Appendix (continued)

\begin{tabular}{|c|c|c|}
\hline Name & Location & Contribution \\
\hline $\begin{array}{l}\text { Thaís } \\
\text { Armangue, } \\
\text { MD, PhD }\end{array}$ & $\begin{array}{l}\text { Sant Joan de Déu Children's } \\
\text { Hospital, IDIBAPS and } \\
\text { Hospital Clinic, Barcelona, } \\
\text { Spain }\end{array}$ & $\begin{array}{l}\text { Designed and } \\
\text { conceptualized the } \\
\text { study, followed the } \\
\text { patients, and drafted } \\
\text { and reviewed the } \\
\text { manuscript }\end{array}$ \\
\hline $\begin{array}{l}\text { Laia Alsina, } \\
\text { MD, PhD }\end{array}$ & $\begin{array}{l}\text { Sant Joan de Déu Children's } \\
\text { Hospital, Barcelona, Spain }\end{array}$ & $\begin{array}{l}\text { Designed and } \\
\text { conceptualized the } \\
\text { study, followed the } \\
\text { patient, and drafted and } \\
\text { reviewed the } \\
\text { manuscript }\end{array}$ \\
\hline
\end{tabular}

\section{References}

1. Worch J, Makarova O, Burkhardt B. Immunreconstitution and infectious complications after rituximab treatment in children and adolescents: what do we know and what can we learn from adults? Cancers (Basel) 2015;7:305-328.

2. Okroj M, Österborg A, Blom AM. Effector mechanisms of anti-CD20 monoclonal antibodies in B cell malignancies. Cancer Treat Rev 2013;39:632-639.

3. Kavcic M, Fisher BT, Seif AE, et al. Leveraging administrative data to monitor rituximab use in 2875 patients at 42 freestanding children's hospitals across the United States. J Pediatr 2013;162:1252.e1-1258 e1.

4. Sacco KA, Abraham RS. Consequences of B-cell-depleting therapy: hypogammaglobulinemia and impaired B-cell reconstitution. Immunotherapy 2018;10: 713-728.

5. Christou EAA, Giardino G, Worth A, Ladomenou F. Risk factors predisposing to the development of hypogammaglobulinemia and infections post-rituximab. Int Rev Immunol 2017;36:352-359.

6. Kimby E. Tolerability and safety of rituximab. Cancer Treat Rev 2005;31:456-473.

7. Kado R, Sanders G, McCune WJ. Suppression of normal immune responses after treatment with rituximab. Curr Opin Rheumatol 2016;28:251-258.

8. Memon $\mathrm{AB}$, Javed A, Caon C, et al. Long-term safety of rituximab induced peripheral B-cell depletion in autoimmune neurological diseases. PLoS One 2018;13:e0190425.

9. Kollmann TR. Development of immunity in early life. J Infect 2015; (suppl 1): S112-S120.

10. KDIGO (kidney diseases improving global outcome) 2012. Clinical practice guidelines for glomerulonephritisAvailabel at: kdigo.org/wp-content/uploads/2017/ 02/KDIGO-2012-GN-Guideline-English.pdf. Accessed September 1, 2019.

11. Kearsley-Fleet L, Sampath S, McCann LJ, et al. Use and effectiveness of rituximab in children and young people with juvenile idiopathic arthritisin a cohort study in the United Kingdom. Rheumatology (Oxford) 2019;58:331-335.

12. Stingl C, Cardinale K, Van Mater H. An update on the treatment of pediatric autoinmune encephalitis. Curr Treatm Opt Rheumatol 2018;4:14-28.

13. Schatorjé EJ, Gemen EF, Driessen GJ, et al. Age-matched reference values for B-lymphocyte subpopulations and CVID classifications in children. Scand J Immunol 2011;74:502-510.

14. Soldin SJ. Pediatric Reference Ranges, 2nd ed. Washington, DC: AACC. Press; 1997.

15. Rao A, Kelly M, Musselman M, et al. Safety, efficacy, and immune reconstitution after rituximab therapy in pediatric patients with chronic refractory hematologic autoimmune cytopenias. Pediatr Blood Cancer 2008;50:822-825.

16. Quartier P, Brethon B, Philippet P, Landman-Parker J, Le Deist F, Fischer A. Treatment of childhood autoimmune haemolytic anaemia with rituximab. Lancet 2001;358:1511-1513.

17. Dale RC, Brilot F, Duffy LV, et al. Utility and safety of rituximab in pediatric autoimmune and inflammatory CNS disease. Neurology 2014;83:142-150.

18. Barmettler S, Ong MS, Farmer JR, Choi H, Walter J. Association of immunoglobulin levels, infectious risk and mortality with rituximab and hypogammaglobulinemia. JAMA Netw Open 2018; 1:e184169.

19. Roberts DM, Jones RB, Smith RM, et al. Rituximab-associated hypogammaglobulinemia: incidence, predictors and outcomes in patients with multisystem autoimmune disease. J Autoimmun 2015;57:60-65.

20. Kamei K, Ito S, Nozu K, et al. Single dose of rituximab for refractory steroiddependent nephrotic syndrome in children. Pediatr Nephrol 2009;24: 1321-1328.

21. Zarkhin V, Li L, Kambham N, Sigdel T, Salvatierra O, Sarwal MM. A randomized, prospective trial of rituximab for acute rejection in pediatric renal transplantation. Am J Transpl 2008;8:2607-2617.

22. Bennett CM, Rogers ZR, Kinnamon DD, et al. Prospective phase $1 / 2$ study of rituximab in childhood and adolescent chronic immune thrombocytopenic purpura. Blood 2006;107:2639-2642. 
23. Reddy V, Martinez L, Isenberg DA, Leandro MJ, Cambridge G. Pragmatic treatment of patients with systemic lupus erythematosus with rituximab: long-term effects on serum immunoglobulins. Arthritis Care Res (Hoboken) 2017;69:857-866.

24. Tallantyre EC, Whittam DH, Jolles S, et al. Correction to: secondary antibody deficiency: a complication of anti-CD20 therapy for neuroinflammation. J Neurol 2018, 265;1123

25. Khojan AM, Miller ML, Klein-Gitelman MS, et al. Rituximab-associated hypogammaglobulinemia in pediatric patients with autoimmune diseases. Pediatr Rheumatol Online J 2019;17:61.

26. Looney RJ, Srinivasan R, Calabrese LH. The effects of rituximab on immunocompetency in patients with autoinmune disease. Arthritis Rheum 2008;58:5-14.

27. Leandro MJ. B-cell subpopulations in humans and their differential susceptibility to depletion with anti-CD20 monoclonal antibodies. Arthritis Res Ther 2013;15(suppl 1):S3.
28. Beum PV, Kennedy AD, Williams ME, Lindorfer MA, Taylor RP. The shaving reaction: rituximab/CD20 complexes are removed from mantle cell lymphoma and chronic lymphocytic leukemia cells by TPH-1 monocytes. J Immunol 2006;176: 2600-2609.

29. Marco H, Smith RM, Jones RB, et al. The effect of rituximab therapy on immunoglobulin levels in patients with multisystem autoimmune disease. BMC Musculoskelet Disord 2014;15:178.

30. Venhoff N, Effelsberg NM, Salzer U, et al. Impact of rituximab on immunoglobulin concentrations and B cell numbers after cyclophosphamide treatment in patients with ANCA-associated vasculitides. PLoS One 2012;7:e37626.

31. Patel SY, Carbone J, Jolles S. The expanding field of secondary antibody deficiency: causes, diagnosis, and management. Front Inmunol 2019;8:33. 


\section{Neurology \\ Neuroimmunology \& Neuroinflammation}

\section{Single-cycle rituximab-induced immunologic changes in children: Enhanced in neuroimmunologic disease? \\ Angela Deyà-Martínez, Yadira Gordón, Cristina Molina-Anguita, et al. \\ Neurol Neuroimmunol Neuroinflamm 2020;7; \\ DOI 10.1212/NXI.0000000000000724}

This information is current as of May 6, 2020

\section{Updated Information \& \\ Services}

References

Subspecialty Collections

Permissions \& Licensing

Reprints including high resolution figures, can be found at:

http://nn.neurology.org/content/7/4/e724.full.html

This article cites 28 articles, 2 of which you can access for free at: http://nn.neurology.org/content/7/4/e724.full.html\#\#ref-list-1

This article, along with others on similar topics, appears in the following collection(s):

All Demyelinating disease (CNS)

http://nn.neurology.org//cgi/collection/all_demyelinating_disease_cns

All Immunology

http://nn.neurology.org//cgi/collection/all_immunology

All Pediatric

http://nn.neurology.org//cgi/collection/all_pediatric

Information about reproducing this article in parts (figures,tables) or in its entirety can be found online at:

http://nn.neurology.org/misc/about.xhtml\#permissions

Information about ordering reprints can be found online:

http://nn.neurology.org/misc/addir.xhtml\#reprintsus

Neurol Neuroimmunol Neuroinflamm is an official journal of the American Academy of Neurology.

Published since April 2014, it is an open-access, online-only, continuous publication journal. Copyright

Copyright (C) 2020 The Author(s). Published by Wolters Kluwer Health, Inc. on behalf of the American

Academy of Neurology.. All rights reserved. Online ISSN: 2332-7812.

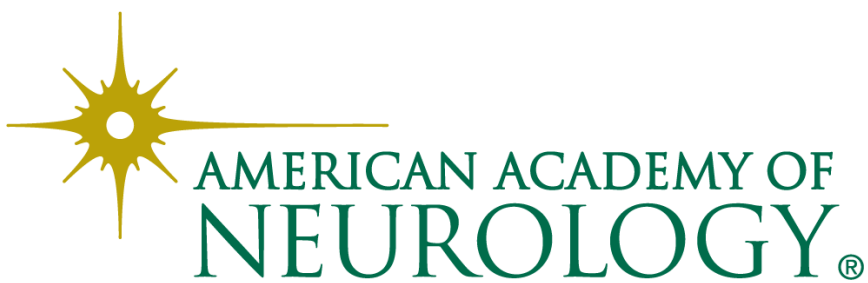

